\title{
Adverb of Time Analysis on Novel "After the Ending” By Lindsey Fairleigh
}

Amanda Ariffani Sholikha ${ }^{1}$

Lilia Indriani ${ }^{2}$

${ }^{1}$ Corresponding author, Universitas Tidar, Indonesia; Amanda.ariffani.sholikha@students.untidar.ac.id

${ }^{2}$ Universitas Tidar, Indonesia; indriani@untidar.ac.id

Received: June 5, $2021 \quad$ Accepted: July 15, $2021 \quad$ Published: July 29, 2021

\begin{abstract}
Reading is an activity that EFL students always do. They can read a textbook or even a novel in their leisure time. Reading activity reads the paragraph, sentence, and text. However, as EFL students, they must understand what they read for study and improve their knowledge about the structural grammar and the function of the words by reading kind of books like a novel. In grammar, there is a term part of speech. Part of speech is divided into five parts: Noun, Verb, Adjective, Adverb, and Preposition. In this time, students can focus on Adverb, mainly Adverb of time, to know and understand about Adverb of time and function in the novel's story already read. This article is descriptive qualitative research that aims to identify Adverbs of time from the novel After the Ending by Lindsey Fairleigh. Adverbs of time may appear in several sentences in this novel. This study shows how many Adverbs of time appear in the story and the function of Adverb of time in the story.
\end{abstract}

Keywords: Adverb of time; after the ending; Lindsey Fairleigh.

To cite this article: Sholikha, A., \& Indriani, L. (2021). Adverb of time analysis on novel "After the Ending” By Lindsey Fairleigh. SALEE: Study of Applied Linguistics and English Education, 2(2), 155-162. https://doi.org/10.35961/salee.v2i02.270 


\section{Introduction}

In learning English, as EFL students, we certainly have to understand specific learning skills, including reading skills. In reading ability, students must understand and know the meaning from the text that is already read. Reading is a process carried out and used by readers to obtain messages, which the writer intends to convey through the media of written words or language. A process that demands that a group of words that constitute a whole be seen at a glance and that the meaning of individual words will be known. If this is not fulfilled, then the expressed and implied message will not be caught or understand, and the reading process will not be carried out correctly (Hodgsonin Tarigan, 2008:7).

Reading some books like novels can also develop reading comprehension skills through novels that students already read, so there are construct meaning by interacting with the text and understanding the grammatical and the topic that already read to study. A reader should know understanding the reading passage Cooper (1986:11)

The purpose of reading apart from gaining knowledge is expected to understand what has been read and understand the meaning of each sentence and recognize groups of words in language units based on categories of form, function, and meaning in the grammatical system (part of speech). The major ones consist of nouns, verbs, adjectives, and adverbs, while the minor ones includes pronouns, wh-words, articles, auxiliary verbs, prepositions, intensifiers, conjunctions, and particles (Delahunty and Garvey, 2010:147). In the part of speech, adverb also often found in the sentence, adverbs in a sentence have function to complete or add information like what adjectives do. According to Goris Keraf as cited in Susanti (2009: 35) Adverbs themselves can be generally classified into some types: adverbs of time, adverbs of place, adverbs of manner, etc. They have their functions in modifying sentences or even clauses. In this article we will focuses on Adverb of Time, Adverb of time is part of Adverb that tells when something happened and expresses a point in time (Learning English Online, 2018). Furthermore, usually adverb of time used to describe when something happens. In the book of Basic Grammar of English, second edition (2015).

These adverbs of time are often used:

1) To talk about the past ( yesterday, the day before, ago, last week/month/year)

2) To talk about the present (still, yet, while, when)

3) To talk about the future (soon, then, next week/month/year, in 2 days, tomorrow, the day after tomorrow)

There are some previous researches related to this article. First, it is carried out by Saputra from Faculty of Letters and Culture Udayana University (2017) with his research entitled Adverb of Place in 6 Balinese Folktales. This research is to classify the functions of Adverb of place that found in Balinese Folktales with conclusion the writer found adverb of place that often appear are formed as complement of preposition that have function filled the story to explain a place, for example: at and from can occur with other preposition.

The second research is written by Fauzi from Diponegoro University (2020) with his research entitled Adverb of Time in Arabic Simple Sentence. This research is to describe the pattern of Arabic simple sentence attached by adverb of time with conclusion the writeronly found that the adverbial elements in Arabic simple sentence in verb that come from the original verb and not derived from the verb. 
Third article written by Antika from STIKP National (2020) with her research entitled The Ability of English Department Students' in Using Adverb Clauses of Time. This research describes students' ability in using adverb clauses of time for past, present, and future time at State University of Padang, the writer concluded that the English Department Students' ability in using the adverb clauses of time generally weak and most of the students confused and got difficult to find the correct tense for dependent and independent clauses.

From some article references above, there are similarities and differences between this article, the similarities is same as using adverbs to wrote the article and find the function of adverbs itself in the story, novel or object being studied so the writer can find out how the adverbs functions and kind of adverbs that appears are used in the object being analyzed. The differences are kinds of adverbs and the object that used in the article the writer analyze.

Based on some article references, this article will identify the adverb of time and analyze the function of adverb of time in the novel After the Ending by Lindsey Fairleigh, amounting to 407 pages include the cover.

\section{Method}

This research uses qualitative research method. A qualitative descriptive research method is a method used by researchers to find knowledge or theories about research at a certain time Mukhtar (2013: 10). The data are taken from novel After the Ending by Lindsey Fairleigh that consists of 51 chapters and 407 pages. The steps are reading the novel, analyze adverb of time in the novel, analyze function of adverb of time in the novel, draw conclusion from the results of data analysis, and make conclusion in the form of descriptive research based on the results of analysis.

\section{Finding and Discussion}

\subsection{Finding}

This research is focused on adverb of time and analysis function adverb of time in novel After the Ending by Lindsey Fairleigh. All data were taken from the novel and analysis adverb of time are often used like yesterday, the day before, ago, last week/month/year, still, yet, while, when, soon, then, next week/month/year, in 2 days, tomorrow, the day after tomorrow.

After analyzing the data, can show the result how many often adverb of time appears in novel and from the data can know what word from adverb of time that mostly appears and the reason and the function that word in the story.

\subsubsection{Result from analyze adverb of time talk about the past.}

The result of the occurences of adverb of time about the past (Yesterday, the day before, ago, last week/month/year) used in the novel is presented in Table 1 below. 
Table1. The number uses of adverb of time

\begin{tabular}{cc}
\hline Adverb of time (talk about past) & Count \\
\hline Yesterday & 12 \\
The day before & 1 \\
Ago & 119 \\
Last week & 5 \\
Last month & 1 \\
\hline TOTAL & $\mathbf{1 3 8}$ \\
\hline
\end{tabular}

The highest adverb of time that talks about Past is the word "ago." This word has a meaning to express of time with past tense to show how far in past something happened and it is used in many contexts such as:

(1) As I cleared the last crosswalk on the way back home, being careful to avoid the puddles left by the morning rain. I wondered if the outbreak would end up being as deadly as the Spanish flu was nearly a century ago. I shook my head, dispelling my unusually grim thoughts. It's just the flu, I told myself for the hundredth time. She'll be fine. They all will (Chapter 1)

(2) She's so pale and weak. Actually, she looks just like you did when you had that H1N1 virus a few years ago. Cam's been making soup for her... he's so sweet. Besides, his cooking is a gazillion time better than whatever I'd conjure up. (Chapter 1)

(3) I was confused, knowing he'd been about to say something entirely different. Regardless, I said, "I need to talk to Zoe." "The phones went down a little bit ago." (Chapter 5)

(4) "It was that damn virus... we had it... weeks ago," Chris said, gesturing around the room even though it was empty of anyone but us. "Several days back, everyone in the world seemed to be infected. Now pretty much everyone is dead. (Chapter 5)

So, it can be summarized the word "ago" is used for express something happen before in context above.

The lowest adverb of time that talks about Past is the word "the day before" and "last month", these words have a meaning same with ago that express of time to show how far in past something happened and it used in contexts:

(1) I took less offense as the years passed, knowing he was a royal mess when it came to Mom, whose birthday was the day before mine. (Chapter 12)

(2) I know things haven't been easy for you the last month or so, but I guarantee you'll be safer with us. (Chapter 24) 


\subsubsection{Result from analyze adverb of time talk about the present.}

Table2. The number uses of adverb of time talk about the present

\begin{tabular}{cc}
\hline Adverb of time (talk about present) & Count \\
\hline Still & 190 \\
Yet & 26 \\
While & 119 \\
When & 381 \\
\hline Total & $\mathbf{7 1 6}$ \\
\hline
\end{tabular}

The highest adverb of time that talks about Present is the word "when." This word has a meaning to express of time with present tense to asking something happen or explain the situation in the story and it is used in many contexts such as:

(1) Rubbing Jack's velvety ear, I decided to write a nice long email to my best friend, Zoe-she had neither answered when I'd called during my walk home nor responded to my texts. The woman worked like crazy, and we hadn't chatted in days. (Chapter 1)

(2) Chris stood and stalked across the living room, pausing when she reached the beautiful, imposing man. She was surprisingly menacing for such a motherly woman. (Chapter 5)

(3) Sanchez's dark eyebrows arched, and she looked like was hiding a smile. "Those of you who want to learn how to protect yourselves, which I encourage each of you to do, come see me," Sanchez told the seven civilian in the room. "Zoe, since you're so keen on the idea, you can start as son as you've healed a bit more." "I think more" "Harper, come off. Or you could just ignore me." When she left, the rest of us returned to our meal, chewing absentmindedly. (Chapter 23)

(4) After finding everything necessary for tea in the kitchen and dampening washcloth warm water, I headed to Tanya's room. I felt like a stranger as I tapped on her door, wondering if I'd be intruding. When I heard her timid voice call for me to come in, I entered. Tanya and Stacey were sitting on the bed, staring at me with drawn face. (Chapter 26)

The lowest adverb of time that talks about Present is the word "yet", this word has a meaning to talk about something that has not happened but that you expect to happen and it used in contexts:

(1) We're not actually setting out on our grand (note the sarcasm) journey into the changed world yet. We still have to gather a ton of supplies. The group has cleaned out a bunch of the packaged and canned foods from the apartments. (Chapter 7) 
(2) He looked amazed. "Both ways? I haven't seen that yet, what about people? (Chapter 27)

(3) I quickly tried to collect myself, but with his arm wrapped around me, his scent assaulted me and derailed my concentration yet again. (Chapter 28)

(4) It was a little longer than it had been when he'd found me in my Seattle apartment, but not yet long enough to show the loose curl I knew it held. (Chapter 36)

\subsubsection{Result from analyze adverb of time talk about the future.}

Table3. The number uses of adverb of time talk about the future

\begin{tabular}{cc}
\hline Adverb of time (talk about the future) & Count \\
\hline Soon & 54 \\
Then & 152 \\
Next day & 1 \\
Tomorrow & 28 \\
Next year & 2 \\
\hline Total & $\mathbf{2 3 7}$ \\
\hline
\end{tabular}

The highest adverb of time that talks about the future is the word "then." This word has a meaning to refer to a particular time in the future in this story and it is used in many contexts such as:

(1) Uneasiness settled inside me like vines tangling in my stomach. Dave's eyes narrowed and then widened as he registered the revulsion on my face. Rolling onto his back, he looked up the ceiling. He was embarrassed. I could feel him simmering in it, thick and sticky like his breath. (Chapter 12)

(2) Harper's amicable voice perked my mood up like a thirsty flower given water. "I went by your room, but you weren't there." He nodded to Jake, then caught my eye and motioned toward the doors. (Chapter 24)

(3) "I know what I'm going to miss," Dave said, interrupting my happy recollections. "Red Sox games." I rolled my eyes. Surprise. "What about you, Jake?" Search asked. He was the only one at the table who hadn't said anything. He glanced at me, then around the table. (Chapter 24)

(4) Jason did nothing to defend himself. "NO!' I leapt at Cam but couldn't grasp any part of his melting skin. I gagged. He lifted his face and swallowed I'll make him part of me, you'll see. Then you'll have to love me again. (Chapter 27) 
The lowest adverb of time that talks about the future is the word "next day", this word has a meaning to refer to time in the future on this story and it used in contexts:

(1) The next day, I woke up alone in my bed. I'd slept through the whole night, not even stirring when Sarah left. As humiliated as I should've been after my complete meltdown, I was just grateful for a full night's sleep. Knowing there was much to do before I left Fort Knox, I readied myself for the day. After throwing on a sweatshirt, I pulled on a pair of jeans, ran a brush.(Chapter 36)

\subsubsection{Result of total adverb of time appears at novel After the Ending by Lindsey Fairleigh}

Table4. Total of adverb of time appears.

\begin{tabular}{cc}
\hline Adverb of time & Count \\
\hline Talk about past & 138 \\
Talk about present & 761 \\
Talk about the future & 237 \\
\hline Total & $\mathbf{1 . 1 3 6}$ \\
\hline
\end{tabular}

\subsection{Discussion}

The results of this article focus on analyzing adverb of time that used in the novel which discusses more specifically part of the adverbs section than the previous research, this result use table content of amount the data to show the function of adverb of time and total how much appears in the novel then give some proof sentences or paragraph that contains the elements. For the previous research that analyze adverbs usually just show the results with gave the evidence of sentences or paragraph contains the elements. This article can supports the previous research because this article analyzes specific adverb and gives different ways to show the results and uses the different object to analyze the adverb of time that can be referenced for another writer that will do similar research.

Based from data above word "when" is often appears in the novel After the Endingby Lindsey Fairleigh, for example in sentence "Rubbing Jack's velvety ear, I decided to write a nice long email to my best friend, Zoe - she had neither answered when I'd called during my walk home nor responded to my texts. The woman worked like crazy, and we hadn't chatted in days." (Chapter 1) word "when" at that sentence has function as adverb of time that explain time while "I" character (Dani) while walk home with calling his friend.

And the lowest adverb of time that appears in the novel After the Ending by Lindsey Fairleigh is adverb of time that talk about past with total 138 and words "ago" and "last month" are the lowest with total once appear in the story of the novel.

\section{Conclusion}

Adverbs can be generally into some types, there are adverbs of time, adverbs of place, adverbs of manner, and another. This article focused on adverb of time to analyze the function and how often appears in novel After the Ending by Lindsey Fairleigh. Adverb of time usually describes when something happens in any situations. Adverb of time are often used is classify 
into three part that talk about the past (yesterday, the day before, ago, last week), talk about the present (still, yet, while, when), and talk about the future (soon, then, next week, tomorrow). The part from adverb of time that often appears in novel After the Ending is talk about the future with word "when" that appears in data analysis around 381 words from 1.136 total data. It can be concluded that novel After the Ending are often use adverb of time that talk about Present to explain something happens in the story with applying the word of adverb of time with total 716 from 1.136 data.

\section{References}

Adverb of Time. (2018). Retrieved 2021, from Learnnig English Online.net: https://www.learning-english-online.net/grammar/parts-of-speech-and-sentencestructure/adverbs/adverbs-of-time/

Antika, R. (2020). The Ability of English Departement Students' in Using Adverb Clauses of Time. TELL-US Journal.

Antika, R. (2020). The Ability of English Department Students' in Using Adverb Clauses of Time. TELL-US JOURNAL, 101-118.

Astrid Robertha, Diana Christianti and Brenda Pricilia. (2015). Basic Grammar of English, second edition. . Gramedia Indonesia.

Delahunty. (2010). The English Language from Sound to Sense. Colorado: Parlor Press. Retrieved 2021, from WAC Clearinghouse: https://wac.colostate.edu/books/perspectives/sound/

Delahunty, G. a. (2010, May 21). WAC Clearinghouse. Retrieved March 2021, from wac.colostate.edu: https://wac.colostate.edu/books/perspectives/sound/

Fauzi, M. I. (2020). Adverb of Time in Arabic Simple Sentence. UISU Language Literacy Journal Vol.4, 263-270.

Kreatif, K. (2012, February 24). Reading Comprehension. Retrieved 2021, from muttaqinhasyim.wordpress:

https://muttaqinhasyim.wordpress.com/2012/02/24/reading-comprehension/

Mukhtar. (2013). Metode Praktis Penelitian Deskriptif Kualitatif. GP Press Group.

Robertha, A. (2015). Basic Grammar of English, second edition. . Gramedia Indonesia.

Saputra, G. N. (2017). Adverb of Place in 6 Balinese Folktales. OJS UNUD vol 10.

Sari, D. K. (2012). Sari K.D. 2012. A Syntactic Analysis of Noun Phrase in the Text of Senior High School. Teacher Training and Education Muhammadiyah University of Surakarta. Eprints.ums.ac.id.

Susanti. (2009). An Analysis of Adverb of Manner in Sidney Sheldon's Morning, Noon, and Night and Its Translation into Indonesian by HendartoSetiadi. . eprints.uny.ac.id.

Tarigan. (2008). MembacaSebagaiSuatuKeterampilanBerbahasa. Bandung: Angkasa. 